\title{
Did China Bankroll Russia's Annexation of Crimea? The Role of Sino-Russian Energy Relations
}

Indra Overland and Gulaikhan Kubayeva

\begin{abstract}
This chapter analyses bilateral Chinese-Russian energy relations, pre- and post Crimea. The signing of the Power of Siberia megaproject in May 2014, only two months after Russia's annexation of Crimea, created the impression that China bankrolled Russia out of the crisis. To assess the veracity of this impression, the authors draw a longer timeline of Russian-Chinese cooperation, examining general economic data as well as Chinese involvement in four concrete energy projects managed by leading Russian energy companies. They find that, in general, deals made from 2014 onwards are in line with trends that originated well before the current crisis in Russia's relations with the West, and that Chinese financial contributions to the sector are not as large as they sometimes appear.
\end{abstract}

Keywords Russia $\bullet$ China $\bullet$ Energy $\bullet$ Crimea $\bullet$ Sanctions

\section{Overland $(\bowtie)$}

Energy Programme, Norwegian Institute of International Affairs, Oslo, Norway

G. Kubayeva

The Regional Environmental Centre for Central Asia, Almaty, Kazakhstan

(C) The Author(s) 2018

H. Blakkisrud, E. Wilson Rowe (eds.), Russia's Turn to the East, Global Reordering, https://doi.org/10.1007/978-3-319-69790-1_6 
In the years leading up to the conflict over Ukraine, oil prices were high, Western countries open to cooperation and foreign companies eager to invest in Russia- especially in the petroleum sector. Many Russian companies, including state-controlled oil and gas corporations, took on high levels of debt, based on the assumption that oil prices would remain high. After Crimea, Russia faced not only international sanctions but also a collapse in the price of oil. The combination of the lower oil price and sanctions left Russia economically and politically vulnerable, and potentially dependent on its biggest non-Western trading partner: China.

After the introduction of Western sanctions, several major developments took place in Sino-Russian energy cooperation. In May 2014, the two countries reached a deal on the Power of Siberia natural gas pipeline, with an estimated value of USD 400 billion (Overland et al. 2015, p.42). During the same year, imports of oil from Russia to China increased by 36 per cent, reaching 30 million tons (Cunningham 2015b). Oil exports from Russia even displaced other suppliers: in 2014, Chinese oil imports from Saudi Arabia fell by 8 per cent and from Venezuela by 11 per cent (Cunningham 2015a; see Fig. 6.1 for further details). This development was one important motivation behind Saudi Arabia's unexpected decision to raise oil production and lower the price of oil in 2014, despite the negative impact on Saudi revenues and on intra-OPEC solidarity.

These developments create the impression that China was discreetly providing the financial backing for Russia's annexation of Crimea. While

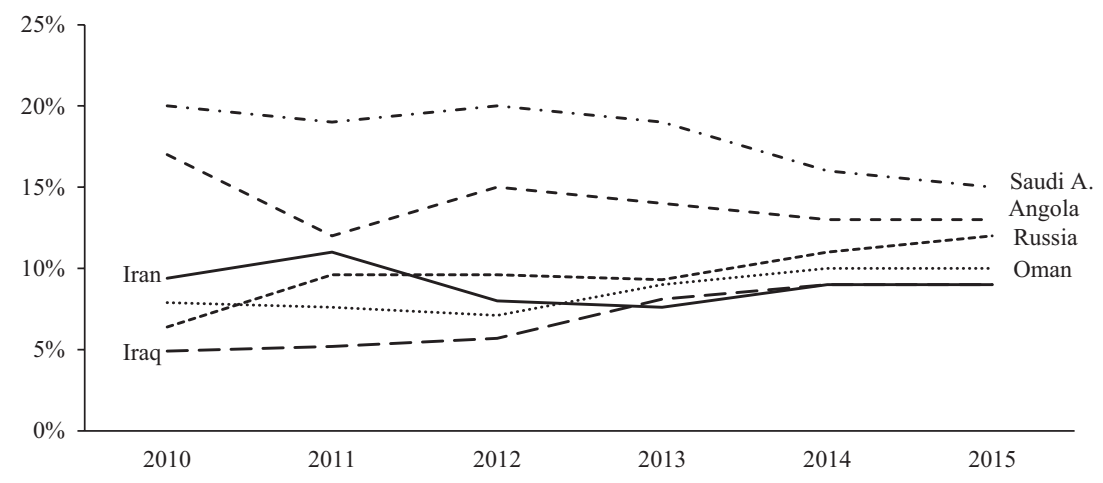

Fig. 6.1 Chinese oil imports, by country of origin, main suppliers (Sources: Observatory of Economic Complexity 2014; Workman 2016) 
Western countries were trying to choke Russia's cash supply, China seemed to be stepping in to fill the financial void. As Margarete Klein and Kirsten Westphal wrote: 'After its relations with the West deteriorated massively in the course of the Ukraine crisis, Russia has been aligning itself increasingly with China. This shift is most obvious in the strategic spheres of military and energy cooperation' (Klein and Westphal 2016, p.1; see also Gabuev 2015, p.2; Charap et al. 2017, p.25). Did China in practice bankroll Russia after the annexation of Crimea by injecting capital into the Russian energy sector?

During the pre-Crimea period of rising oil prices (2000-14, with a dip in 2008), it was not clear whether the relationship between China and Russia was doomed to remain a mere 'axis of convenience' (Lo 2008, p.1), or whether the strategic convergence between the two states-complementary assets, common outlook and shared interests-gave the relationship greater potential (Braekhus and Overland 2007; Overland and Braekhus 2009; Røseth 2017, p. 23). The Ukraine crisis and the ensuing Western sanctions would seem to have provided a unique opportunity for realizing whatever potential lies in the relationship.

This chapter approaches the Ukraine crisis as a natural quasi-experiment to which the Sino-Russian relationship has been subjected. If the relationship between the two countries has the potential to grow, the Ukraine crisis should have provided ideal conditions for this potential to be realized. In order to determine whether China really did step in and actively provide the financing to carry Russia through this period, it is necessary to analyse systematically whether the trajectory of Sino-Russian energy cooperation changed in connection with the Crimea crisis.

Throughout the chapter, we seek to provide a systematic and multifaceted empirical basis for the analysis by drawing on the relevant data that are available. In the next section we present the sanctions against Russia and their consequences, and discuss the Chinese approach to the sanctions. We then chart and compare changes in patterns of economic interaction between China and Russia in the years before and after the annexation of Crimea: lending, investments and trade. After discussing those macro-data, we examine Chinese involvement in four specific energy projects managed by some of Russia's main energy companies: Gazprom/Power of Siberia, Novatek/Yamal LNG, Rosneft/Vankor and Transneft/ESPO. Next, we look back on Sino-Russian relations since the 
collapse of the Soviet Union, in order to relate post-Crimea developments to the long-term trend in relations. In the final section we offer some conclusions and discuss the prospects for a deeper relationship between China and Russia.

\section{Sanctions Against Russia}

In response to Russia's annexation of Crimea, the EU, the United States and several other Western countries and allies implemented three types of sanctions: a ban on the provision of technology and equipment for deepwater, Arctic offshore and shale oil and gas exploration; a ban on mid- and long-term credit to Russian oil companies and state banks; and travel bans for prominent Russians considered to be involved in the annexation of Crimea or close to President Vladimir Putin. Our focus is on the economic sanctions. Table 6.1 provides an overview of their main targets. One of the banks included in the sanctions list was Gazprombank, and several of the others were heavily involved in the petroleum sector. In sum, the economic sanctions were largely centred on the Russian oil industry.

The referendum on Crimea's reunification with Russia was held on 16 March 2014, and the first sanctions were implemented the following day. This date is thus a key time-point in our analysis: did Chinese financing for Russian energy projects make a jump around that time?

Table 6.1 Main EU and US economic sanctions against Russia

\begin{tabular}{lll}
\hline $\begin{array}{l}\text { Ban on equipment for oil } \\
\text { industry }\end{array}$ & $\begin{array}{l}\text { Financial ban on oil and gas } \\
\text { companies }\end{array}$ & Financial ban on banks \\
\hline $\begin{array}{ll}\text { Deep water } \\
\text { Offshore Arctic }\end{array}$ & Gazprom & Bank of Moscow \\
Shale oil production & Lukprom Neft & Gazprombank \\
& Rosneft & InvestCapital Bank \\
& Sakhatrans & JSB Sobinbank \\
& SGM Pipeline Construction & Rosselkhozbank \\
& Stroitransgaz & Sberbank \\
& Surgutneftegaz & Vneshekonombank \\
& Transneft & VTB Bank \\
& Transoil & \\
& &
\end{tabular}

Note: This overview is non-exhaustive, as sanctions varied over time and by country Sources: Dunn and Smith (2014), Fjaertoft and Overland (2015, p.66) 


\section{China's Stance on the Sanctions}

At first China maintained a neutral position on the Ukraine crisis. The Chinese abstained from voting on a 15 March UN Security Council resolution declaring the results of the Crimean referendum on reunification with Russia invalid - but they did not use their right of veto as one of the Permanent Five (Zhang, Lihua 2015). Chinese banks adhered de facto to the Western sanctions, with the exception of the Export-Import Bank of China and China Development Bank (Pravda.ru 2016).

This wait-and-see stance made some sense. It offered a precarious balance between, on the one hand, China's traditionally conservative view on interference in the internal affairs of other states and its preoccupation with maintaining its own territorial integrity (Taiwan, Tibet and Xinjiang) and, on the other hand, its growing friendship with Russia and dislike for the Western meddling in Ukrainian politics that had prefaced the conflict (see Lanteigne, Chap. 7, this volume).

Gradually, however, China tilted moderately towards the Russian position on Crimea. On 6 June 2014, the Secretary of the Russian Security Council and former Director of the Federal Security Service, Nikolai Patrushev, stated that China and Russia had arrived at a common understanding of the Ukrainian crisis (TV Tsentr 2014); and in February 2015 the Chinese Ambassador to Belgium, Qu Xing, expressed support for the Russian point of view and encouraged the West to end its quarrel with Russia (Boren 2015). However, it is difficult to determine the extent of China's tilt towards the Russian position: it is hard to find clear proRussian statements from policymakers in Beijing, and the level of Chinese support was played up by the Russians.

\section{Patterns of Economic Interaction Between China AND RUSSIA}

Data on the Sino-Russian economic relationship give a mixed picture. As shown in Fig. 6.2, borrowing from China by Russian companies and households did rise in 2014 and 2015. However, that trend had started in 2013, before the Ukraine crisis. Thus, it is difficult to know whether the rise in borrowing was simply the continuation of a trend that had begun earlier and was not related to events in Ukraine, or was reinforced by the Ukraine crisis. On the other hand, there was also a spike in Russian borrowing from China in 2008-09, when Russia experienced a severe financial 
25,000

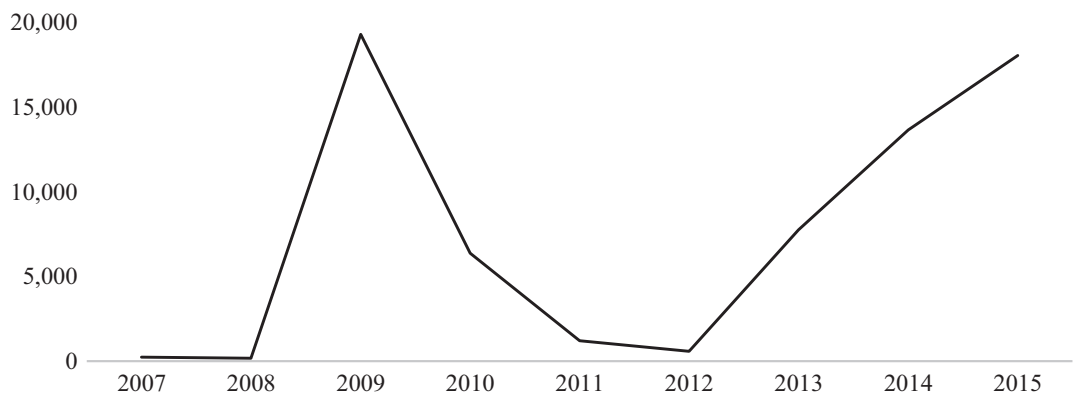

Fig. 6.2 Loans of Russian non-bank entities from China, million USD (Source: Calculated based on data from the Central Bank of Russia, available at http:// www.cbr.ru/eng/statistics/?PrtId=svs. Accessed on 26 March 2017)

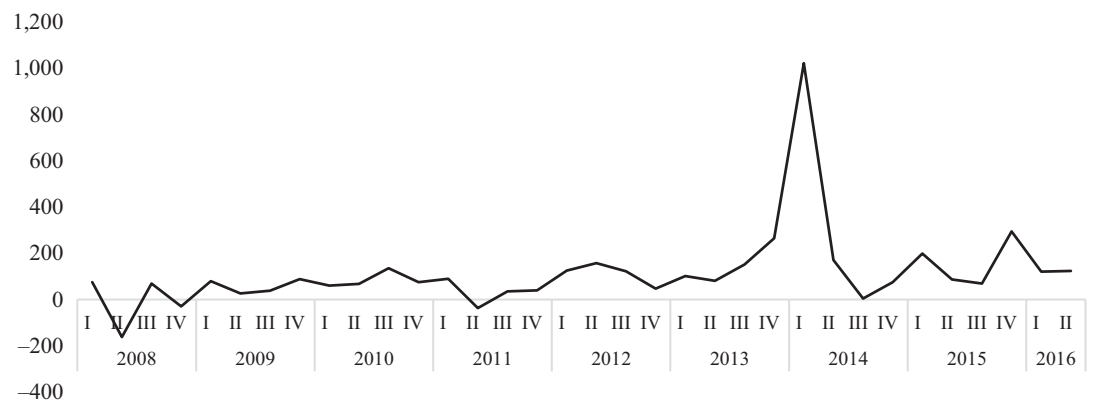

Fig. 6.3 FDI from China to Russia, million USD (Source: Calculated based on data from the Central Bank of Russia, available at https://www.cbr.ru/statistics/ credit_statistics/inv_in-country.xlsx. Accessed on 26 March 2017)

crisis. Seen together, these two spikes could indicate that Russia turns to China when cash becomes scarce.

As shown in Fig. 6.3, there was a large jump in Chinese foreign direct investment (FDI) in Russia in early 2014. However, that came in the first quarter of that year, whereas economic sanctions were not introduced until the beginning of the second quarter, in mid-April. Thus the jump in Chinese FDI is not likely to be related to the sanctions regime, although it might have been mobilized in anticipation of sanctions. Another possible 
explanation is that it might be related to the Power of Siberia deal, although this deal was officially announced only in May. In any case, the jump was only to one billion USD. Although that was a significant divergence from the long-term pattern of FDI, it is a relatively small sum for a country such as Russia, and much smaller than the impact of sanctions or the falling oil price.

Finally, it is worth considering whether increased sales of oil and gas to China buoyed the Russian economy during this period. As shown in Fig. 6.4, Russia's income from oil exports to China rose only modestly in 2014 , and then actually fell in 2015. Income from the sale of coal to China fell continuously and steeply from 2013 to 2015. The reason for these declines was mainly the lower international prices for energy commodities-which neither China nor Russia controls. But at least it is clear that income from energy exports to China did not rise and save the Russian economy.

Thus, the patterns of lending, investments and energy trade between China and Russia spanning the pre- and post-Crimea years do not point towards a major role for China in keeping Russia's wheels turning during

Oil

Gas and coal

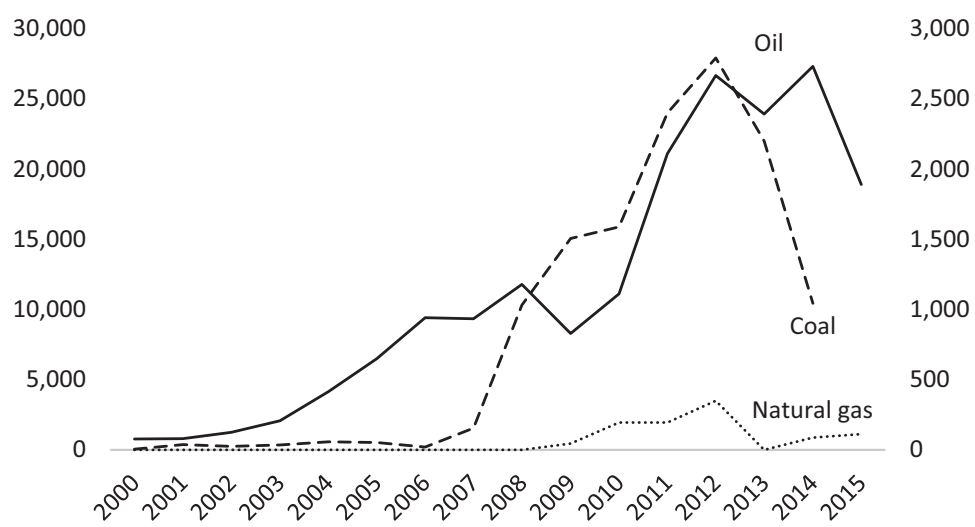

Fig. 6.4 Russian income from the export of oil, gas and coal to China, million USD (Source: Based on data on import of 'coal, coke and briquettes', 'petroleum, petroleum products and related materials', 'gas, natural and manufactured' from Russia to China, retrieved from https://comtrade.un.org/data. Accessed on 10 October 2016) 
this period. Although the data on lending and FDI may appear interesting at first glance, and offer some striking graphics, on closer inspection we find little of significance there.

\section{Sino-Russian Energy Projects}

We now turn to the petroleum sector and examine four large energy projects in which the Chinese and the Russians have attempted to cooperate. All four involve major Russian oil and gas companies that have been subject to Western sanctions: Transneft, Gazprom, Novatek and Rosneft. Did the role of the Chinese in these projects change after the Ukraine conflict?

\section{Transneft: ESPO Pipeline}

The Eastern Siberia-Pacific Ocean (ESPO) oil pipeline was constructed and is managed by Russia's state-owned oil pipeline monopoly Transneft, the world's largest oil pipeline company. The history of Sino-Russian discussions of ESPO goes many years back. The construction of ESPO was first mooted in the 1970s. In 1994, President Boris Yeltsin proposed building a pipeline from Angarsk (Irkutsk Oblast) to China. In 1996, after long negotiations, Beijing and Moscow signed an agreement on energy cooperation, including plans for a pipeline from Eastern Siberia to Daqing in northern China. However, the cooperation moved slowly, partly due to the difficult investment climate in Russia, and partly because China sought concessions from the Russians on pricing.

In 1999, the head of the privately owned oil company Yukos, Mikhail Khodorkovskii, conducted negotiations with China National Petroleum Corporation (CNPC) on the construction of ESPO, and in 2001 Prime Minister Mikhail Kasianov signed an agreement on feasibility studies for the pipeline (Kommersant 2006). Russian and Chinese oil companies started technical-economic assessments for the project, and it was expected that the leaders of the two countries would sign an agreement in December 2002. But the negotiations slowed down again, this time because Japan showed interest in paying for a pipeline from East Siberia to the Pacific coast. The Russian government decided to merge the Chinese and Japanese projects into one project that would go to Kozmino on the Pacific coast (Driakin 2014, pp.102-10). 
There was also competition between Yukos and the state oil pipeline monopoly Transneft. The government decided that Transneft would be in charge of the pipeline and Yukos would supply the oil (Helmer 2008). In May 2003, China and Russia agreed on the construction of the pipeline (ChinaDaily.com 2003), and the work started in April 2006 (Koyama 2010). Meanwhile Khodorkovskii had been arrested and most of Yukos assets confiscated by the state. While various sections of the pipeline were being built, interim arrangements were made to pump oil in reverse through a section of the pipeline and transport it by rail part of the way (Bryanski 2009; Watkins 2009). The second stage of the pipeline was inaugurated in December 2012.

In April 2009, China and Russia agreed to build a spur to Daqing through which Russia would supply China with 15 million tons of oil per year for 20 years in exchange for a USD 25 billion loan to Transneft and Rosneft. Construction of the spur from the Russian side started in April 2009 and was completed by September 2010 (BBC Monitoring 2009; Page 2010). On l January 2011, Russia announced that oil shipments to China had commenced.

By 2015, ESPO capacity had risen to 58 million tons per year, and the branch line from the Russian town of Skovorodino to Daqing to 15 million tons per year (Platts 2015) (Table 6.2).

Table 6.2 Timeline of Sino-Russian cooperation on ESPO pipeline

\begin{tabular}{|c|c|}
\hline Date & Development \\
\hline July 2001 & $\begin{array}{l}\text { Russian and Chinese prime ministers sign agreement on feasibility studies } \\
\text { for ESPO }\end{array}$ \\
\hline May 2003 & China and Russia agree on the construction of the pipeline \\
\hline Dec. 2004 & Russian government approves the construction of ESPO \\
\hline Apr. 2006 & Construction of pipeline starts \\
\hline June 2009 & China and Russia agree to build a spur to Daqing in China \\
\hline Dec. 2009 & First stage of the pipeline completed \\
\hline Sept. 2010 & Daqing spur completed \\
\hline Jan. 2011 & Shipments via Daqing commence \\
\hline Dec. 2012 & Second stage of the pipeline completed \\
\hline June 2016 & $\begin{array}{l}\text { Work on second pipe of Daqing spur commences, to double spur capacity } \\
\text { to } 30 \mathrm{mt} / \text { year }\end{array}$ \\
\hline Oct. 2017 & Daqing spur second pipe scheduled for completion \\
\hline
\end{tabular}




\section{Gazprom: Power of Siberia}

The Power of Siberia pipeline will be the largest gas transmission system in eastern Russia, transporting natural gas from Irkutsk and Sakha to the Russian Far East, partly for production of liquefied natural gas (LNG) on the Pacific coast, partly for pipeline export to China. The 4000-kilometre long pipeline will link the Kovykta gas and condensate field in Eastern Siberia and the Chaiandinskoe oil, gas and condensate field in Sakha to the existing Sakhalin-Khabarovsk-Vladivostok pipeline. The fields are scheduled to come on stream in 2021 and 2019, respectively (Gazprom 2016; Sidortsov et al. 2016, pp.54-68).

After a cooperation agreement had been signed between Gazprom and CNPC in 2004, Sino-Russian natural gas negotiations went on for more than ten years. Initially, the parties discussed a pipeline through Altai, linking the rich gas fields of the NadymPurTaz area in West Siberia to the northwestern corner of China. The length of this pipeline would be 2800 rather than 4000 kilometres, and the price of the gas would be lower, because it would initially draw on gas fields already in production. It would also have put China in direct competition with Europe for West Siberian gas. But the Chinese rejected the Altai route because it would take gas to one of the most remote and sparsely populated parts of China, which can be supplied with gas from Turkmenistan and local Chinese fields (Anker et al. 2010; Overland et al. 2010; Klein and Westphal 2016, p.4).

In 2009, China and Russia signed an agreement on major terms and conditions for the supply of gas which detailed the terms of actual implementation. While negotiations with the Chinese continued, Gazprom started preparations for developing the Chaiandinskoe gas field and planning the Power of Siberia pipeline. Even though a deal with the Chinese still had not been finalized, in late October 2012 President Putin instructed Gazprom to start building the pipeline (Interfax.ru 2012).

Disagreement on the price of the gas to flow through the pipeline postponed the signing of the final contract from November 2013 to January 2014 - and then to the St Petersburg Economic Forum in May 2014. Only then could Putin, who flew in to the forum at the last moment directly from negotiations in Shanghai, present a deal. The signing of the agreement with China was presented as a major geopolitical victory: a narrow escape from dependence on the capricious European market and the 
Table 6.3 Timeline of Sino-Russian cooperation on Power of Siberia

Date Development

Nov. 2004 Gazprom and CNPC sign cooperation agreement

March 2006 CNPC signs MoU with Gazprom on supplying natural gas from Russia to China

Dec. 2009 Gazprom and CNPC sign agreement on major terms and conditions for gas supply to China

May 2014 Gazprom and CNPC sign a contract to supply gas to China via Power of Siberia

June 2014 Gazprom accelerates the construction of infrastructure related to Power of Siberia

Aug. 2014 Gazprom and Chinese leaders enhance the bilateral strategic partnership in the gas sector

Sept. 2014 Power of Siberia construction launched

Oct 2014 Gazprom and CNPC discuss the negotiation schedule for gas supply to China via Altai

Feb. 2015 The parties address the state of the Altai negotiations

June 2015 Further negotiations on gas supply via Altai

Aug. 2015 Further negotiations on gas supply via Altai

Nov. 2015 The parties discuss the progress of the construction of the Power of Siberia gas pipeline.

Dec. 2015 Negotiations on finalization of agreement on cross-border section of Power of Siberia

Dec. 2015 The parties discuss both Power of Siberia and Altai

May 2016 Gazprom and the Chinese review possible joint activities relating to hydrocarbon exploration and production, including LNG

June 2016 Gazprom and CNPC discuss gas supplies via Altai in detail

June 2016 Gazprom and CNPC sign MoU on underground gas storage and gas-fired power generation

July 2016 Gazprom and CNPC agree on roadmaps for implementing MoU on underground gas storage and gas-fired power generation

Aug. 2016 Gazprom and Chinese Ambassador Li Hui make positive statements about Sino-Russian cooperation in gas sector

Sept. 2016 Gazprom and CNPC sign contract on underwater border crossing for Power of Siberia 
yoke of Western sanctions. However, the agreement was also criticized. Detractors argued that the price paid by the Chinese would not cover the costs of the project, that Russia's political interests had prevailed over its economic interests, and that China had taken advantage of the situation (Prelovskaia 2014).

On 21 May 2014, the heads of Gazprom and CNPC signed the Power of Siberia contract to supply 1032 trillion cubic metres of gas to China over a 30-year period. The total value of the contract exceeded USD 400 billion. Gazprom estimated that it would need five years to build the pipeline, at a cost of USD 55 billion (Prelovskaia 2014). Construction started on 1 September 2014 in Sakha, in the presence of President Putin and Deputy Chinese Prime Minister Zhang Gaoli (TASS 2014).

While the construction of the Power of Siberia is ahead of schedule (Gazprom 2017), negotiations over an additional pipeline via Altai have been slow and no final deal appears to be on the horizon (Astakhova and Kobzeva 2017). Klein and Westphal (2016, p.4) refer to this pipeline as 'a remote prospect at best' (Table 6.3).

\section{Novatek: ramal LNG}

Yamal LNG is a liquefied natural gas plant on the Yamal Peninsula in northwestern Siberia (Yamal LNG 2015). The project has a budget of USD 27 billion and will increase Russia's LNG capacity twofold, with initial production starting in 2017 and full capacity reached by 2021 (Belinski 2015). Discussions about Yamal LNG started in the early 2000s; the project was initially owned by some Russian oligarchs and then the company Novatek, a rising star in Russia's natural gas sector. Novatek brought international companies into the project, with the sale of a 20 per cent stake to French Total in 2011 and a 20 per cent stake to CNPC in 2013 (Bros and Mitrova 2016).

Although the Western sanctions are not supposed to affect Russian natural gas supplies to Europe, Yamal LNG was one of the largest projects to face financial problems after the introduction of sanctions. Novatek has limited access to the pipelines to Europe, and Yamal LNG will export gas to European and above all Asian markets in the form of LNG by tanker. The sanctions applied not only to Novatek but also to its daughter companies, including Yamal LNG, as the owners are seen as being closely connected with President Putin (Lunden et al. 2013, p.668; Overland et al. 2013, p.145). Novatek had planned to borrow USD 20 billion from 
Table 6.4 Timeline of Sino-Russian cooperation on Yamal LNG

\begin{tabular}{|c|c|}
\hline Date & Development \\
\hline June 2013 & $\begin{array}{l}\text { Novatek and CNPC conclude framework agreement on the Yamal LNG } \\
\text { project }\end{array}$ \\
\hline Sept. 2013 & Novatek sells 20 per cent share of Yamal LNG to CNPC \\
\hline March 2014 & $\begin{array}{l}\text { Russia and China sign an agreement on cooperation on the Yamal LNG } \\
\text { project. The Chinese commit to buying at least three million tons of } \\
\text { LNG per year and secure financing for the project from Chinese financial } \\
\text { institutions }\end{array}$ \\
\hline March 2014 & $\begin{array}{l}\text { Yamal LNG and Fluxys (Belgium) sign cooperation agreement on LNG } \\
\text { trans-shipment }\end{array}$ \\
\hline May 2014 & $\begin{array}{l}\text { Binding contract on LNG from Yamal is concluded with CNPC. China } \\
\text { Development Bank, Vneshekonombank, Gazprombank and Yamal LNG } \\
\text { sign MoU on project financing }\end{array}$ \\
\hline Jan. 2015 & $\begin{array}{l}\text { Gazprom Singapore and Yamal Trade sign long-term LNG supply } \\
\text { agreement }\end{array}$ \\
\hline Apr. 2015 & $\begin{array}{l}\text { Yamal LNG and Fluxys sign contract for LNG shipment services at } \\
\text { Zeebrugge LNG }\end{array}$ \\
\hline Nov. 2015 & $\begin{array}{l}\text { Yamal LNG receives second tranche of funding from Russian National } \\
\text { Wealth Fund }\end{array}$ \\
\hline Apr. 2016 & $\begin{array}{l}\text { Yamal LNG signs agreements with the Export-Import Bank of China and } \\
\text { the China Development Bank on two } 15 \text {-year loans for a total amount } \\
\text { exceeding USD } 12 \text { billion }\end{array}$ \\
\hline June 2016 & Yamal LNG receives first tranche of funds from Chinese banks \\
\hline Dec. 2016 & $\begin{array}{l}\text { Yamal LNG gets EUR } 200 \text { million credit line from Japan Bank for } \\
\text { International Cooperation }\end{array}$ \\
\hline
\end{tabular}

US and European banks. After the introduction of sanctions, the Russians lost access to US banks and negotiated with Chinese banks and European export agencies instead. Meanwhile, the shareholders were forced to finance the project independently (Barsukov and Mordiushenko 2016). In 2016, however, Yamal LNG received loans from Chinese and Japanese state banks worth USD 12 billion and EUR 200 million, respectively. Negotiations on loans from Chinese banks had started in 2014, but grew out of deals signed in mid- and late 2013 (Farchy 2016) (Table 6.4).

\section{Rosneft: Vankor}

The Vankor cluster of oil and gas fields in Siberia, discovered in 1988, is currently the largest source of oil in Russia, with recoverable reserves of 361 million tons of oil and condensate and 138 billion cubic metres of gas 
Table 6.5 Timeline of Sino-Russian cooperation on Vankor field

\begin{tabular}{|c|c|}
\hline Date & Development \\
\hline Apr. 1988 & Discovery of Vankor oil field \\
\hline Feb. 2004 & Rosneft subsidiary Vankorneft founded \\
\hline Aug. 2009 & Formal launch ceremony for commercial production at the Vankor field \\
\hline Jan. 2013 & The Vankor field produce their 50 -millionth ton of oil \\
\hline Nov. 2013 & $\begin{array}{l}\text { Rosneft's Board of Directors approves Vankorneft as the operator of three } \\
\text { fields: Lodochnoe, Suzunskoe and Tagulskoe }\end{array}$ \\
\hline Dec. 2013 & 70 million tons of oil produced at the field cumulatively \\
\hline Sept. 2014 & Putin suggests participation in project to Chinese Deputy Prime Minister \\
\hline June 2016 & $\begin{array}{l}\text { Oil India, Indian Oil and Bharat PetroResources purchase } 23.9 \text { per cent of } \\
\text { Vankorneft's shares }\end{array}$ \\
\hline
\end{tabular}

(Panteleev 2006; Gan 2015). Rosneft has invested USD 5 billion in Vankor; production started in 2009 (Gan 2015). Vankor will send 70 per cent of its oil through the ESPO pipeline.

There was little discussion of foreign investment in Vankor until September 2014, when Putin suggested during a meeting with Chinese Deputy Prime Minister Zhang Gaoli that the Chinese take part in the project. Two months later, Rosneft and CNPC signed a memorandum of intention on the sale of a 10 per cent share of Vankor. However, the parties were unable to turn the memorandum into an agreement (Motoharu 2016). Instead, in March 2016 Rosneft signed a deal with Indian companies on the sale of 23.9 per cent of Vankor (Rosneft 2016). Through this purchase, the Indian companies gained seats on the Board of Directors, while Rosneft retained a majority stake in the project. During the rest of 2016, Rosneft and the Indian companies negotiated further sale of Vankor shares, potentially bringing the Indian stake up to 49.9 per cent (Sputnik 2016) (Table 6.5).

\section{Summing Up the Four Projects}

The four major projects examined here do not indicate any significant change in Chinese involvement in the Russian energy sector after the Ukraine crisis. In three of them, discussions on Chinese involvement started well before the crisis. The exception is the Vankor project, but it ultimately did not result in Chinese investment. It may be that finalization of the Power of Siberia deal was accelerated due to the Ukraine crisis, but also this was something that had been planned and negotiated intensively 
for a long time, so we should take care not to exaggerate the connection with the Ukraine crisis.

\section{The Long-Term Perspective}

The previous sections sought to identify the dynamics of Sino-Russian cooperation around the time of the annexation of Crimea. It may also be helpful to examine the longer lines in the relationship between the two countries to determine whether the cooperation from 2014 onwards represented something new triggered by the Ukraine crisis, or was an extension of a more long-term trend that pre-dated the crisis.

Relations between the Chinese and Soviet communist behemoths were rarely warm and frequently tense (Henderson and Mitrova 2016, p.1). Warding off a potential Chinese attack was a main reason for the emphasis that the Soviets put on their tactical nuclear weapons (Trenin 1999, p.41; Yost 2001, p.550). Moreover, during a seven-month period in 1969, there were actually military clashes along the Sino-Soviet border, leaving scores of Chinese and Soviet soldiers dead. During the post-Soviet period, relations improved steadily-upgraded incrementally, first to 'constructive partnership' (1994), then 'strategic partnership of cooperation' (1996) and then 'comprehensive deepening strategic partnership' (2010) (Klein and Westphal 2016, p.1). Another sign of the improvement was the finalization of agreements delimiting the border between the two countries in 1991, 1994, 1998, 1999 and 2004 (Moe et al. 2011, p.153).

In the energy sector, an important part of the long-term picture is the evolution of Chinese demand for Russian energy resources (Aguilera et al. 2013). Energy security became a strategic aspect of Chinese foreign policy when the country became a net importer of oil in 1993 (Overland and Braekhus 2009). Dependence on oil imports continued to grow, from 70 million tons in 2000 to 336 million tons by 2015 (Hsu 2016). The Chinese government took an active approach to energy security, including it in the Tenth Five-Year Plan (2001-2005). Among the measures proposed were the building of pipelines from Kazakhstan and Russia, and increasing Chinese investments in international oil exploration and field operations.

In 2013, China had a natural gas deficit of 6.7 billion cubic metres. The Chinese National Reform and Development Commission has forecast that demand for natural gas in 2020 will be 411 billion cubic metres, whereas domestic production will be only 200 billion-necessitating a steep rise in imports (Prelovskaia 2014). Although the international gas trade is 
Table 6.6 Sino-Russian energy deals and developments

\begin{tabular}{|c|c|}
\hline & Deal \\
\hline 2001 & $\begin{array}{l}\text { Russian company Yukos proposes Eastern Siberia-Pacific Ocean (ESPO) oil } \\
\text { pipeline }\end{array}$ \\
\hline 2003 & $\begin{array}{l}\text { CNPC signs a framework agreement with Sakhalin Energy on exploration and } \\
\text { development }\end{array}$ \\
\hline 2004 & Gazprom and CNPC sign cooperation agreement \\
\hline 2005 & China lends Russia USD 6 billion to help finance Yukos deal \\
\hline 2005 & CNPC signs agreement on long-term cooperation with Rosneft \\
\hline 2006 & $\begin{array}{l}\text { CNPC signs MOU with Gazprom, Rosneft and Transneft on supplying natural } \\
\text { gas }\end{array}$ \\
\hline 2006 & CNPC buys a USD 500 million stake in Rosneft \\
\hline 2006 & CNPC signs strategic cooperation agreement with Lukoil \\
\hline 2006 & CNPC and Rosneft establish the joint venture Vostok Energy \\
\hline 2007 & Vostok Energy wins a bid for oil and gas exploration licences in Irkutsk \\
\hline 2008 & CNPC and Transneft sign agreement to build oil pipeline to China \\
\hline 2009 & $\begin{array}{l}\text { China, Rosneft and Transneft agree to supply } 15 \text { million tons annually for } 20 \\
\text { years from East Siberia for USD } 25 \text { billion }\end{array}$ \\
\hline 2009 & $\begin{array}{l}\text { China signs framework agreement with Gazprom on natural gas supply and } \mathrm{MoU} \\
\text { with Rosneft }\end{array}$ \\
\hline 2010 & Oil pipeline to China officially starts to operate \\
\hline 2011 & China agrees to contribute USD 1 billion to China-Russia Investment Fund \\
\hline 2012 & $\begin{array}{l}27 \text { business deals, worth USD } 15 \text { billion, signed at Sino-Russian investment } \\
\text { forum }\end{array}$ \\
\hline 2012 & China Development Bank and Sberbank agree to cooperate \\
\hline 2013 & Chinese investment in Russian coal worth USD 2 billion \\
\hline 2013 & $\begin{array}{l}\text { Rosneft deal to supply oil to China, with USD } 70 \text { billion prepaid (total value } \\
\text { USD } 270 \text { billion) }\end{array}$ \\
\hline 2013 & CNPC buys 20 per cent of Novatek's Yamal LNG project \\
\hline 2013 & China lends USD 1.9 billion to Russian banks \\
\hline 2014 & 30-year Power of Siberia natural gas deal signed, worth USD 400 billion \\
\hline 2014 & $\begin{array}{l}\text { CNOOC gets contract for engineering at Novatek-led Yamal LNG project worth } \\
\text { USD } 1.6 \text { billion }\end{array}$ \\
\hline 2016 & $\begin{array}{l}\text { Yamal LNG signs agreements with the Export-Import Bank of China and the } \\
\text { China Development Bank on two } 15 \text {-year loans for a total amount exceeding } \\
\text { USD } 12 \text { billion }\end{array}$ \\
\hline
\end{tabular}

Sources: Ministry of Foreign Affairs (2001), Gazprom (2004), White and Chazan (2005), Paxton and Soldatkin (2009), Zhang, Chi (2015)

increasingly competitive and there are some alternatives to Russia as supplier, there is little doubt that China will need significant amounts of Russian gas. Table 6.6 provides an overview of Sino-Russian energy deals and developments over time, and shows that the cooperation had gained momentum well before the 2014 Ukraine crisis. 
Thus it has long been clear that Russian energy resources are of great interest to the Chinese and the Chinese market is of great interest to the Russians (Locatelli et al. 2017, p.159). The two countries had already been moving two steps forward, one step back on energy cooperation for two decades before the Ukraine crisis. The Chinese deals with Gazprom on Power of Siberia and with Novatek on Yamal LNG were logical continuations of this dance and helped resolve long-standing Chinese energysecurity concerns (Overland 2015, p.3532). Russian oil exports to China doubled between 2010 and 2014-before the Ukraine crisis (Klein and Westphal 2016, p.5). In this perspective, the energy cooperation from 2014 onwards fits into a longer-term trend towards greater energy trade between the two countries. ${ }^{1}$

\section{CONCLUSions}

In some respects, Chinese involvement and financing did surge in the aftermath of the Ukraine crisis. After many years of slow negotiations, there was an increased frequency in meetings to discuss major energy projects like Power of Siberia, one of the largest energy deals in world history.

However, in most cases the deals from 2014 onwards fit with trends that had started well before the crisis. The Chinese financial contribution was not as large as it might seem at first sight; and, in some cases, it did not continue beyond 2014 into 2015 and 2016 (Motoharu 2016). The failure to reach an agreement on the Vankor project and the fact that the boom in Chinese FDI did not last beyond the first quarter of 2014 are examples of the slowdown. In sum, we find little basis for arguing that China bankrolled Russia's annexation of Crimea.

Several factors may have hindered a surge in Sino-Russian energy cooperation. First, both sides are often determined to have a controlling role in partnerships, and that makes it difficult to close deals, even when the interests of the two countries are complementary (Rosbalt.ru 2016). Second, the Russian oil and gas companies managed to weather the storm better than expected due to the precipitous drop in the value of the Russian ruble: while their income from oil and gas exports fell, also their costs in Russia fell, cancelling out a good part of the foreign earnings loss. Thus Russian companies did not become as dependent on Chinese help as might have been expected. Third, the Russian government maximized the public relations potential of Power of Siberia and other deals with the 
Chinese. On the one hand, this means that the role of the Chinese may have been psychologically more important than the financial data show (O'Sullivan 2016, p.23); on the other hand, it also means that the media image of the role of the Chinese was exaggerated.

What then are the implications of our findings for the depth and longterm prospects of the Sino-Russian relationship? To some extent they confirm Bobo Lo's argument that it is an 'axis of convenience' (Lo 2008). When the Russians need financing or markets, they seek out the Chinesebut not more than necessary. When the Chinese need natural resources, they buy them from Russia-but only if the price is right (Simola 2016, p.3; Henderson and Mitrova 2016, p.1). This has not amounted to a deeper relationship where the two countries identify with each other. The fact that even with the Ukraine crisis the surge in Sino-Russian cooperation was modest, indicates that the relationship still has limited potential. Thus, Lo's 'axis of convenience' perspective seems to have weathered the natural quasi-experiment of the Ukraine crisis quite well.

However, the fact that the cooperation from 2014 onwards fits with longer-term trends can also be read the other way around. Although the Ukraine crisis did not lead to a sudden strengthening of Sino-Russian relations, it represents an international context increasingly conducive to cooperation between China and Russia, a relationship that has already been growing for a quarter of a century. If this continues for a long period, the two countries may well grow closer over time. After all, it is not so long since the Russians 'discovered' China in earnest: it was only in 2012 President Putin told Russian gas producers to look east (cited in O'Sullivan 2016, p.22). In the future, the two countries may yet grow closer.

Another way to read the Ukraine crisis and the ensuing jump in economic complementarity between China and Russia is that it shows that, for the relationship to become qualitatively different, things will have to happen not only at the economic level but also at the level of culture, identity and ideology. Otherwise Sino-Russian relations will remain a marriage of convenience in which either partner may lose interest as soon as the economic complementarities fade.

Acknowledgements This chapter is a product of the RusChange research project, which is financed by the PETROSAM II Programme of the Research Council of Norway. 


\section{Notes}

1. This finding echoes that by Tom Røseth $(2017$, p.37).

\section{REFERENCES}

Aguilera, Roberto, Julian Inchauspe and Ronald Ripple. 2013. 'The Asia Pacific natural gas market: large enough for all?’ Energy Policy 65: 1-6.

Anker, Morten, Pavel Baev, Bjørn Brunstad, Indra Overland and Stina Torjesen. 2010. The Caspian Sea region towards 2025: Caspia Inc., national giants or trade and transit? Delft: Eburon.

Astakhova, Olesya and Oksana Kobzeva. 2017. 'Russia-China talks over new gas routes stalled: sources', Renters, 7 June. http://www.reuters.com/article/usrussia-china-energy-idUSKBN18Y1TX. Accessed on 3 July 2017.

Barsukov, Iurii and Ol'ga Mordiushenko. 2016. 'S oporoi na sobstvennye sily' [Relying on one's own strength]. Kommersant, 30 April. http://kommersant. $\mathrm{ru} / \mathrm{doc} / 2978177$. Accessed on 30 December 2016.

BBC Monitoring. 2009. 'Chinese envoy to Russia: oil pipeline serves strategic goals of both sides', 11 May. http://downstreamtoday.com/news/article. aspx?a_id=16321\&AspxAutoDetectCookieSupport=1. Accessed on 30 December 2016.

Belinski, Scott. 2015. 'Putin may have last laugh over Western sanctions', Oilprice. com, 2 April. http://oilprice.com/Energy/Energy-General/Putin-May-HaveLast-Laugh-Over-Western-Sanctions.html. Accessed on 30 December 2016.

Boren, Zackary Davies. 2015. 'Ukraine crisis: top Chinese diplomat backs Putin and says West should "abandon zero-sum mentality", The Independent, 27 February. http://www.independent.co.uk/news/world/europe/ukraine-crisis-top-chinese-diplomat-backs-putin-says-west-should-abandon-zero-summentality-10075762.html. Accessed on 30 December 2016.

Braekhus, Kyrre and Indra Overland. 2007. 'A match made in heaven? Strategic convergence between China and Russia', China and Eurasia Forum Quarterly 5(2): 4l-6l.

Bros, Aurelie and Tatiana Mitrova. 2016. 'Yamal LNG: an economic project under political pressure', Fondation pour la Recherche Stratégique. https://www. frstrategie.org/publications/notes/web/documents/2016/201617.pdf. Accessed on 30 December 2016.

Bryanski, Gleb. 2009. 'Russia's Putin launches new Pacific oil terminal', Reuters, 28 December. http://uk.reuters.com/article/russia-putin-terminal-idUKLD E5BR00F20091228? sp=true. Accessed on 30 December 2016.

Charap, Samuel, John Drennan and Pierre Noël. 2017. 'Russia and China: a new model of great-power relations', Survival 59(1): 25-42. 
ChinaDaily.com. 2003. 'China, Russia sign oil pipeline agreement', 29 May. http://www.chinadaily.com.cn/en/doc/2003-05/29/content_166888.htm. Accessed on 30 December 2016.

Cunningham, Nick. 2015a. 'Russia and China's growing energy relationship', Oilprice.com, 28 January. http://oilprice.com/Energy/Energy-General/ Russia-and-Chinas-Growing-Energy-Relationship.html. Accessed on 30 December 2016.

Cunningham, Nick. 2015b. 'The battle for China's oil market', Oilprice.com, 15 July. http://oilprice.com/Energy/Crude-Oil/The-Battle-For-Chinas-OilMarket.html. Accessed on 30 December 2016.

Driakin, Andrei. 2014. 'Energeticheskaia diplomatiia Rossii v aziatskotikhookeanskom regione: osnovnye aspekty i napraveliia' [Russia's energy diplomacy in the Asia-Pacific: key aspects and trends], Izvestiia vysshikh uchebnykh zavedenii. Povolzhskii region 4: 102-10.

Dunn, Alan and Jennifer Smith. 2014. 'U.S. added 17 companies and 7 individuals, including Rosneft CEO Sechin, to Russia sanctions list and further restricted exports to certain Russian entities; EU, Canada, and Japan also stepped up sanctions', Stewart and Stewart, 1 May. http://www.stewartlaw.com/Article/ ViewArticle/1000. Accessed on 27 December 2016.

Farchy, Jack. 2016. 'Chinese lend \$12bn for gas plant in Russian Arctic', Financial Times, 29 April. https://www.ft.com/content/4ca8886e-0e14-11e6-ad8067655613c2d6. Accessed on 5 February 2017.

Fjaertoft, Daniel and Indra Overland. 2015. 'Financial sanctions impact Russian oil, equipment export ban's effects limited', Oil and Gas Journal 113(8): 66-72.

Gabuev, Alexander. 2015. "A “soft alliance"? Russia-China relations after the Ukraine crisis', European Council on Foreign Relations Policy Brief 126. http:// www.ecfr.eu/page/-/ECFR126_-_A_Soft_Alliance_Russia-China_Relations_ After_the_Ukraine_Crisis.pdf. Accessed on 9 February 2017.

Gan, U. 2015. 'Spetsial'nyi reportazh: “zhemchuzhina v rossiiskoi korone” Vankorskoe neftegazovoe mestorozhdenie' [Special report: 'a pearl in the Russian crown' - the Vankor field], Russian.news.cn, 31 March. http://russian.news.cn/economic/2015-03/31/c_134113387.htm. Accessed on 30 December 2016.

Gazprom. 2004. 'Gazprom and CNPC signed a cooperation agreement', 14 October. http://www.gazprom.com/press/news/2004/october/article62935. Accessed 30 December 2016.

Gazprom. 2016. 'Power of Siberia', http://www.gazprom.com/about/production/projects/pipelines/built/ykv. Accessed on 30 December 2016.

Gazprom. 2017. 'Over 1,100 kilometers of Power of Siberia gas pipeline to be completed by late 2017', 8 June. http://www.gazprom.com/press/news/ 2017/june/article335985/. Accessed on 3 June 2017. 
Helmer, John. 2008. 'China ties up Russia's crude - again', Asia Times, I November. http://www.atimes.com/atimes/China_Business/JK0lCb0l. html. Accessed on 30 December 2016.

Henderson, James and Tatiana Mitrova. 2016. 'Energy relations between Russia and China: playing chess with the dragon', OIES Paper 67. https://www. oxfordenergy.org/wpcms/wp-content/uploads/2016/08/Energy-Relationsbetween-Russia-and-China-Playing-Chess-with-the-Dragon-WPM-67.pdf. Accessed on 9 February 2017.

Hsu, Jenny W. 2016. 'China's crude oil imports rise 8.8\% in 2015', Marketwatch. com, 26 January. http://www.marketwatch.com/story/chinas-crude-oilimports-rise-88-in-2015-2016-01-26. Accessed on 25 December 2016.

Interfax.ru. 2012. “Gazprom” poluchil impul's dlia osvoeniia Chaiandy' [Gazprom received an impetus to develop Chaianda], 29 October. http:// www.interfax.ru/business/273323. Accessed on 30 December 2016.

Klein, Margarete, and Kirsten Westphal. 2016. 'Russia: turn to China?' SWP Comments 7. https://www.swp-berlin.org/fileadmin/contents/products/ comments/2016C07_kle_wep.pdf. Accessed on 29 December 2016.

Kommersant. 2006. 'Istoriia proekta VSTO' [History of the ESPO project], 27 April. http://kommersant.ru/doc/670339. Accessed on 30 December 2016.

Koyama, Ken. 2010. 'Progress made toward operations of China-Russia crude oil pipeline on completion of Russian portion', The Institute of Energy Economics, 3 September. https://eneken.ieej.or.jp/data/3574.pdf. Accessed on 30 December 2016.

Lo, Bobo. 2008. Axis of convenience: Moscow, Beijing, and the new geopolitics. Washington, DC: The Brookings Institution.

Locatelli, Catherine, Mehdi Abbas and Sylvain Rossiaud (2017) 'The emerging hydrocarbon interdependence between Russia and China: institutional and systemic implications', Europe-Asia Studies 69(1): 157-170.

Lunden, Lars Petter, Daniel Fjaertoft, Indra Overland and Alesia Prachakova. 2013. 'Gazprom vs. other gas producers: friends or foes?' Energy Policy 61: $663-70$.

Ministry of Foreign Affairs of the People's Republic of China. 2001. 'Joint statement signed by the Chinese and Russian heads of states', 16 July. http://www. fmprc.gov.cn/mfa_eng/wjdt_665385/2649_665393/t15772.shtml. Accessed on 30 December 2016.

Moe, Arild, Daniel Fjærtoft and Indra Overland. 2011. 'Space and timing: why was the Barents Sea delimitation dispute resolved in 2010?' Polar Geography 34(2): 145-62.

Motoharu, Ikeda. 2016. 'Razmolvka mezhdu Kitaem i Rossiei, i kak ona povliiaet na rossiisko-iaponskie otnosheniia' [The spat between China and Russia, and how it will affect the Russia-Japan relationship], Inosmi.ru, 12 April. http://inosmi. ru/economic/20160412/236092426.html. Accessed on 30 December 2016. 
Observatory of Economic Complexity. 2014. 'Where does China import petroleum oils, oils from bituminous minerals, crude from?' http://atlas.media.mit. edu/en/visualize/tree_map/hs92/import/chn/show/270900/2014. Accessed on 9 February 2017.

O'Sullivan, Meghan. 2016. 'Asia: a geopolitical beneficiary of the new energy environment', in Asia's energy security amid global market change, edited by Muhamad Izham Abd. Shukor, Clara Gillispie, Antoine Halff, Mikkal E. Herberg, Meghan L. O'Sullivan, Leslie Palti-Guzman and Cecilia Tam, 19-30. Seattle, WA: National Bureau of Asian Research.

Overland, Indra. 2015. 'Future petroleum geopolitics: consequences of climate policy and unconventional oil and gas', Handbook of Clean Energy Systems, 3517-44. Chichester: Wiley.

Overland, Indra and Kyrre Braekhus. 2009. 'Chinese perspectives on Russian oil and gas', in Russian energy power and foreign relations, edited by Jeronim Perovic, Robert Orttung and Andreas Wenger, 201-21. Abingdon: Routledge.

Overland, Indra, Jakub Godzimirski, Lars Petter Lunden and Daniel Fjaertoft. 2013. 'Rosneft's offshore partnerships: the re-opening of the Russian petroleum frontier?' Polar Record 49(2): 140-53.

Overland, Indra, Nodari Simonia, Sergey Vasiliev and Elana Wilson Rowe. 2015. 'The international context for Barents oil and gas: Asia's double impact', in International Arctic petroleum cooperation: Barents Sea scenarios, edited by Anatolii Bourmistrov, Frode Mellemvik, Alexei Bambulyak, Ove Gudmestad, Indra Overland and Anatoly Zolotukhin, 35-51. Abingdon: Routledge.

Overland, Indra, Stina Torjesen and Heidi Kjaernet. 2010. 'China and Russia: partners or firewalls for the Caspian petro-states?' in Caspian energy politics: Azerbaijan, Kazakbstan and Turkmenistan, edited by Indra Overland, Heidi Kjaernet and Andrea Kendall-Taylor, 93-100. Abingdon: Routledge.

Page, Jeremy. 2010. 'Russian oil route will open to China', The Wall Street Journal, 26 September. http://www.wsj.com/articles/SB1000142405274870408210 4575515543164948682. Accessed on 30 December 2016.

Panteleev, Vladimir. 2006. 'Ot Kuiumby do Vankora' [From Kuiumba to Vankor], Krasnoiarskii rabochii, 2 September. http://www.krasrab.com/ archive/2006/09/02/07/view_article. Accessed on 30 December 2016.

Paxton, Robin and Vladimir Soldatkin. 2009. 'China lends Russia \$25 billion to get 20 years of oil', Reuters, 17 February. http://uk.reuters.com/article/ukrussia-china-oil-sb-idUKTRE51G3S620090217. Accessed on 22 December 2016.

Platts. 2015. 'China to double Russia ESPO pipeline imports to $30 \mathrm{mil} \mathrm{mt} / \mathrm{year}$ in Oct 2017', 17 September. https://www.platts.com/latest-news/oil/singapore/china-to-double-russia-espo-pipeline-imports-27812989. Accessed on 3 July 2017. 
Pravda.ru. 2016. 'China to join anti-Russian sanctions?' 9 February. http:// www.pravdareport.com/news/world/09-02-2016/133287-china_russia_ sanctions-0. Accessed on 30 December 2016.

Prelovskaia, Vera. 2014. 'Glavnye voprosy i otvety o "samom krupnom stroitel'nom proekte v mire"' [Highlights on 'the biggest construction project in the world'], RBK, 27 November. http://www.rbc.ru/magazine/2014/11/56bc 7e8c9a794701b81d2ba3. Accessed on 30 December 2016.

Rosbalt.ru. 2016. 'SMI: Kitai podderzhal sanktsii protiv Rossii' [Media: China supported sanctions against Russia], 8 February. http://www.rosbalt.ru/ world/2016/02/08/1487611.html. Accessed on 29 December 2016.

Røseth, Tom. 2017. 'Russia's energy relations with China: passing the strategic threshold?', Eurasian Geography and Economics, 58(1): 23-55.

Rosneft. 2016. " "Rosneft" i konsortsium indiiskikh investorov podpisali soglasheniia o vkhozhdenii v Vankorskii proekt' [Rosneft and consortium of Indian investors signed contract on joining Vankor project], 17 June. https://www. rosneft.ru/press/releases/item/182655. Accessed on 30 December 2016.

Sidortsov, Roman, Aytalina Ivanova and Florian Stammler. 2016. 'Localizing governance of systemic risks: a case study of the Power of Siberia pipeline in Russia', Energy Research and Social Science 16: 54-68.

Simola, Heli. 2016. 'Economic relations between Russia and China: increasing inter-dependency?' BOFIT Policy Brief 6. Helsinki: Bank of Finland.

Sputnik. 2016 'Vying for more: India to acquire stake in Russia's Vankor cluster', 13 October. https://sputniknews.com/business/201610131046295545india-vankor-oil. Accessed on 21 February 2017.

TASS. 2014. 'Putin gives start to Power of Siberia gas pipeline construction', 1 September. http://tass.com/economy/747552. Accessed on 30 December 2016.

Trenin, Dmitry. 1999. Russia's China problem. Moscow: Carnegie Endowment for International Peace.

TV Tsentr. 2014. 'Patrushev: Rossiia i Kitai solidarny v svoikh vzgliadakh na ukrainskii krizis' [Patrushev: Russia and China hold similar views on Ukrainian crisis], 6 June. http://tvc.moscow/news/show/id/41593. Accessed on 30 December 2016.

Watkins, Eric. 2009. 'China, Russia agree on loans for ESPO pipeline spur', OileGas Journal, 17 February. http://www.ogj.com/articles/2009/02/ china-russia-agree-on-loans-for-espo-pipeline-spur.html. Accessed 30 December 2016.

White, Gregory L. and Guy Chazan. 2005. 'China lends Russia \$6 billion to help finance Yukos deal', The Wall Street Journal, 2 February. http://www.wsj. com/articles/SB110728599279442584. Accessed on 22 December 2016.

Workman, Daniel. 2016. 'Crude oil imports by country', World's Top Experts, 10 September. http://www.worldstopexports.com/crude-oil-imports-by-country. Accessed on 9 February 2017. 
Yamal LNG. 2015. 'About the project'. http://yamallng.ru/en/project/about. Accessed on 30 December 2016.

Yost, David. 2001. 'Russia's non-strategic nuclear forces', International Affairs 77(3): 531-51.

Zhang, Chi. 2015. The domestic dynamics of China's energy diplomacy. Singapore: World Scientific.

Zhang, Lihua. 2015. 'Explaining China's position on the Crimea referendum', Carnegie-Tsinghua Center for Global Policy, 1 April. http://carnegietsinghua. org/2015/04/01/explaining-china-s-position-on-crimea-referendumpub-59600. Accessed on 30 December 2016.

Open Access This chapter is licensed under the terms of the Creative Commons Attribution 4.0 International License (http://creativecommons.org/licenses/ by $/ 4.0 /)$, which permits use, sharing, adaptation, distribution and reproduction in any medium or format, as long as you give appropriate credit to the original author(s) and the source, provide a link to the Creative Commons license and indicate if changes were made.

The images or other third party material in this book are included in the book's Creative Commons license, unless indicated otherwise in a credit line to the material. If material is not included in the book's Creative Commons license and your intended use is not permitted by statutory regulation or exceeds the permitted use, you will need to obtain permission directly from the copyright holder.

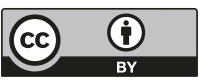

